\title{
Disruption of Microfilaments in Growth Cones following Depolarization and Calcium Influx
}

\author{
M. D. Neely and M. Gesemann \\ Department of Pharmacology, Biozentrum of the University of Basel, $4056 \mathrm{Basel}$, Switzerland
}

Depolarization of leech neurons growing on extracellular matrix extract (ECM) leads to cessation of neurite outgrowth, rounding up of the peripheral regions of the growth cone, loss of filopodia, and neurite retraction. These responses depend on the influx of calcium (Neely, 1993). The aim of the present experiments was to analyze how the cytoskeleton becomes reorganized as growth cones change their morphology.

Immunocytochemistry revealed a loss of microfilaments in the tips of neurites growing on ECM after depolarization. Leech neurons cultured on a different substrate, the plant lectin concanavalin $A$ (ConA), continue to grow during and after depolarization (Grumbacher-Reinert and Nicholls, 1992; Neely, 1993). As expected, we did not observe any change in the distribution of microfilaments after depolarization on ConA. Since there is evidence that this lack of response is due to a reduced calcium influx during depolarization of neurons on ConA (Ross et al., 1988), the effect of the calcium ionophore A23187 on the outgrowth of these cells was analyzed. In the absence of depolarization, this ionophore caused cessation of growth cone motility and a loss of microfilaments, while microtubules were not affected. Cytochalasin D, a microfilament-disrupting agent, induced changes in growth cone morphology and neurite retraction similar to those observed after depolarization and calcium influx. Application of phalloidin, a drug that stabilizes microfilaments, inhibited depolarization-induced retraction of neurites on ECM. By contrast, stabilization of microtubules with taxol did not prevent depolarization from inducing changes in growth cone morphology and neurite growth.

These experiments show that changes in growth cone morphology and motility of leech neurons induced by depolarization and calcium influx are accompanied by a dramatic change in the organization of microfilaments, but not microtubules.

[Key words: calcium, cytoskeleton, depolarization, growth cone, leech, microfilaments, microtubules, neuron]

\footnotetext{
Received Mar. 28, 1994; revised May 20, 1994; accepted May 26, 1994.

We thank our colleague Dr. John G. Nicholls for his unfailing support throughout the work and for his crucial suggestions to improve the manuscript, Dr. W Adams for his skillful help with the video microscopy and helpful comments on the manuscript, and Mr. Bättig for photography. This work was supported by Grant 3127814.89 from the Swiss Nationalfonds to Dr. John G. Nicholls.

Correspondence should be addressed to M. Diana Neely, Department of Pharmacology, Biozentrum of the University of Basel, Klingelbergstrasse 70, 4056 Basel, Switzerland.

Copyright (C) 1994 Society for Neuroscience $0270-6474 / 94 / 147511-10 \$ 05.00 / 0$
}

A major question in neural development concerns the mechanisms that allow neurons to extend long processes that branch in a complicated pattern. After an initial axonal outgrowth that is often excessive, superfluous axons are retracted as the neuron matures (Purves and Lichtman, 1980; Innocenti, 1981; Mariani and Changeux, 1981; Heathcote and Sargent, 1985; Lnenicka and Murphey, 1989). One signal that influences neurite outgrowth is electrical activity (Wiesel and Hubel, 1963, 1965; Hubel and Wiesel, 1970; Lnenicka and Murphey, 1989; Budnik et al., 1990; Shatz, 1990). In culture, changes in neurite outgrowth following activity can often be attributed to raised intracellular calcium concentrations (Anglister et al., 1982; Cohan et al., 1987; Kater et al., 1988; Cohan, 1992; GrumbacherReinert and Nicholls, 1992; Neely, 1993).

The molecular events that underlie the effects of depolarization and influx of calcium on growth cone morphology and neurite outgrowth have not been established. Cell shape and motility have been shown to depend on the structure and dynamics of the cytoskeleton (Yamada et al., 1970, 1971; Spooner et al., 1971; Piatigorsky et al., 1972; Luduena and Wessells, 1973; Letourneau et al., 1986; Forscher and Smith, 1988; Chien et al., 1993; Fan et al., 1993). The most striking changes in depolarized neurites are loss of filopodia and rounding up of the peripheral regions of the growth cone (Cohan and Kater, 1986; Cohan, 1992; Rehder and Kater, 1992; Neely, 1993). The cytoskeleton of the periphery of the growth cone is formed by microfilaments arranged in bundles of parallel filaments in the filopodia and as a submembranous meshwork within the lamcllipodia (Yamada et al., 1970, 1971; Luduena and Wessells, 1973; Letourneau and Ressler, 1983; Forscher and Smith, 1988). The microtubules extend from the neurite shaft and splay into the central area of the growth cone. They occasionally extend into peripheral areas of the growth cone and may enter the filopodia (Yamada et al., 1971; Letourneau and Ressler, 1983; Dailey and Bridgman, 1989). Changing the organization and dynamics of the cytoskeleton with cytoskeletal drugs results in alterations of growth cone morphology and motility (Yamada et al., 1970; Letourneau and Ressler, 1984; Marsh and Letourneau, 1984; Letourneau et al., 1986; Forscher and Smith, 1988). In particular, disruption of microfilaments by cytochalasin leads to retraction of filopodia and rounding up of the growth cones (Yamada et al., 1970, 1971; Marsh and Letourneau, 1984; Bentley and Toroian-Raymond, 1986).

Leech neurons cultured on a substrate of extracellular matrix extract (ECM) respond to depolarization with filopodial loss, rounding up of the peripheral regions of the growth cone, and neurite retraction, a response that depends on the influx of calcium (Neely, 1993). The same neurons growing on concanavalin 

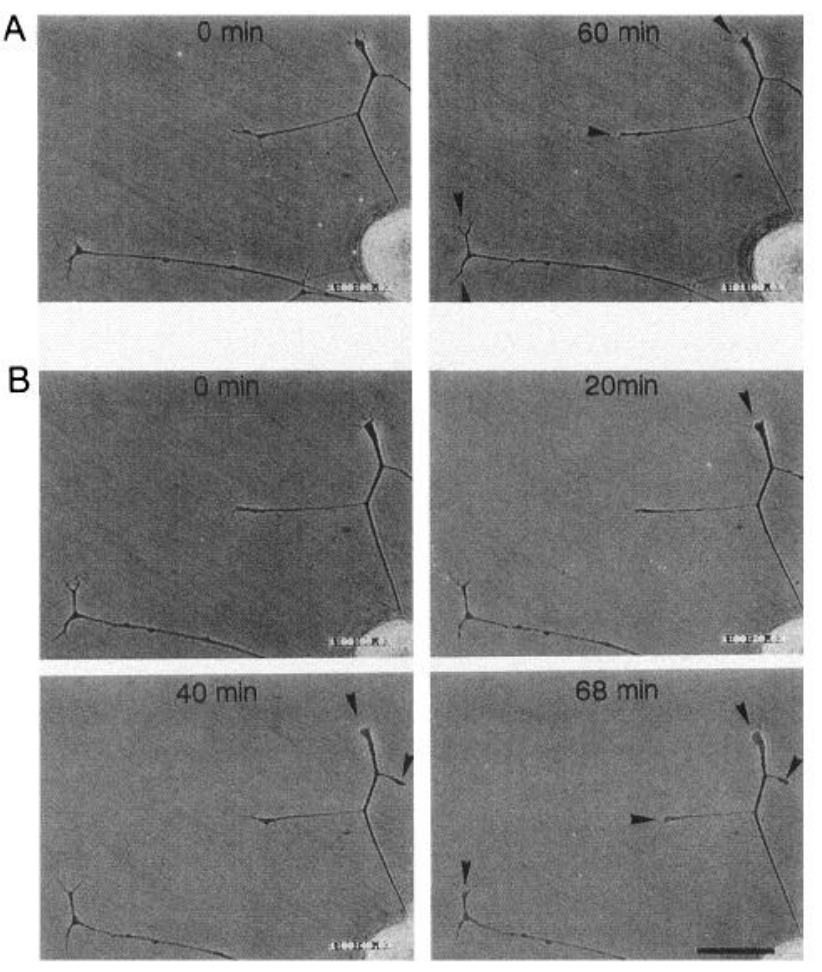

Figure 1. Typical behavior of growth cones in normal medium and after depolarization. After $60 \mathrm{~min}$ in normal medium most of the growth cones of this Retzius cell had extended (A, arrowheads). After $20 \mathrm{~min}$ of exposure to high $\mathrm{K}^{+}$medium the first growth cones started to round up $(B$, arrowhead $)$. After $68 \mathrm{~min}$, all the growth cones in the field of view showed either rounded morphology or the neurites had retracted (B, arrowheads). Scale bar, $50 \mu \mathrm{m}$.

A (ConA) continue to grow when they are depolarized (Grumbacher-Reinert and Nicholls, 1992; Neely, 1993). This behavior of cells growing on ConA correlates well with the lack of voltagedependent calcium channels in their neurites (Ross et al., 1988). In the experiments described here, we show that raising intracellular calcium concentration in neurons on ConA leads to cessation of growth cone motility and retraction of lamellipodia. Depolarization and calcium-induced changes in growth cone morphology of neurites on ECM and ConA are described in relation to alterations in cytoskeletal structure. We show that calcium leads to disruption of microfilaments, whereas microtubules are not affected.

\section{Materials and Methods}

Cell culture. The techniques for the identification, isolation, and culture of neurons from the leech CNS have been described in detail elsewhere (Fuchs et al., 1981; Dietzel et al., 1986). In brief, leech (Hirudo medicinalis; Desbarax, Merignac Cedex, France) ganglion chains were dissected out and pinned in a Sylgard-coated dish (Pluess Staufer AG, Oftringen, Switzerland). The capsules enveloping the ganglia were torn open with forceps and the ganglia incubated with collagenase/dispase ( $2 \mathrm{mg} / \mathrm{ml}$; Essex Chemie AG, Lucerne, Switzerland) in normal medium [L-15 medium (GIBCO) supplemented with gentamicin sulfate $(0.1 \mathrm{mg} /$ ml Garamycin; Essex Chemie AG, Lucerne, Switzerland), glutamine (2 $\mathrm{mm})$, glucose $(6 \mathrm{mg} / \mathrm{ml})$, and $2 \%$ fetal calf serum (GIBCO)] for $1 \mathrm{hr}$ at room temperature. Individual Retzius and anterior pagoda (AP) cells were then removed by suction and plated either on microwell culture dishes (Nunc, IL) or on Lab-Tek chamber slides (Nunc) previously coated either with ConA ( $2 \mathrm{mg} / \mathrm{ml}$; Sigma) for $2 \mathrm{hr}$ or with a lamininenriched EDTA extract of leech extracellular matrix (ECM; prepared as described in Chiquet et al., 1988) for 4-16 hr. The cells were cultured for $1-2 \mathrm{~d}$ at room temperature in normal medium (without fetal calf serum) before analysis by time-lapse video microscopy or immunofluorescence. All experiments were performed with Retzius and AP cells. No difference in the behavior of these two types of neurons was observed in the experiments described here.

Time-lapse video microscopy and growth cone analysis. Growth cones of cells cultured in microwell dishes were observed with phase-contrast optics using an inverted microscope (Leitz-Labovert FS) and a $32 \times$ objective (Leitz, Phaco $132 / 0.40$ ). Images of growth cones were acquired every 4 min by a MTI CCD72 video camera (DAGE-MTI, Inc., Michigan City, IN). Neurites were first observed for $1-2 \mathrm{hr}$ under control conditions and then incubated with different modified media: (1) normal medium containing phalloidin $(10 \mu \mathrm{M})$, taxol $(5 \mu \mathrm{M})$, cytochalasin D (2-10 $\mu \mathrm{M})$, or calcium ionophore A23187 $(0.1 \mu \mathrm{M}$ and $0.2 \mu \mathrm{M})$; (2) high $\mathrm{K}^{+}$medium (prepared by adding isosmolar $\mathrm{KCl}$ and $\mathrm{CaCl}_{2}$ solutions to normal medium to final concentrations of $60 \mathrm{mM}$ for $\mathrm{K}^{+}$and $6 \mu \mathrm{M}$ for $\left.\mathrm{Ca}^{2+}\right)$; (3) high $\mathrm{K}^{+}$medium containing phalloidin $(10 \mu \mathrm{M})$ or taxol (5 $\mu \mathrm{M}$ ); or (4) $\mathrm{Na}^{+}$control medium (this medium was used to control for the resulting dilution of the constituents in normal medium when making high $\mathrm{K}^{+}$medium and was prepared by adding isosmolar $\mathrm{NaCl}$ containing $5.8 \mathrm{mM} \mathrm{KCl}$ and isosmolar $\mathrm{CaCl}_{2}$ to normal medium to final concentrations of $152.4 \mathrm{~mm}$ for $\mathrm{Na}^{+}$and $6 \mathrm{~mm}$ for $\mathrm{Ca}^{2+}$; Neely, 1993). All drugs were purchased from Sigma, except for taxol (Calbiochem, A). Stock solutions of phalloidin were prepared in PBS buffer; stock solutions of cytochalasin, taxol, and calcium ionophore A23187 were made up in DMSO. DMSO concentrations of up to $1 \%$ were tested and had no effect on growth cone motility or neurite outgrowth. DMSO concentrations of the control experiments never exceeded $0.25 \%$. Addition of fetal calf serum to the media had no effect on the behavior of growth cones under all conditions tested, and most experiments were performed without fetal calf serum.

Growth cones on ECM were analyzed for $60 \mathrm{~min}$ and their behavior was categorized as growing (actual elongation of neurites), stable (showing filopodial activity but no neurite elongation), rounding (loss of filopodia and rounding up of growth cones), or retracting (shortening of neurites). Similarly, on ConA the activity of neurites was categorized as growing or stable/retracting. The analysis of the behavior of all growth cones was performed blind by two individuals with virtually the same result. The results were analyzed statistically with contingency table tests.

The rate of neurite growth of cells on ConA was determined by measuring total neurite length before and after $3.5-9.5 \mathrm{hr}$ cytochalasin D treatments (at $2.5 \mu \mathrm{M}$ to $10 \mu \mathrm{M}$ ) and after $15-23.5 \mathrm{hr}$ recovery periods. The lengths were normalized to the total starting neurite length, defined as $100 \%$. The software used to measure neurite length was IMAGE-1 (Universal Imaging). An unpaired two-tailed Student's $t$ test was used for statistical analysis of these experiments.

Immunocytochemistry. Cells that had been cultured on Lab-Tek culture dishes were incubated for 20-30 min with either high $\mathrm{K}^{+}$medium, $\mathrm{Na}^{+}$control medium, or normal medium containing different concentrations of the calcium ionophore A23187 $(0.06-0.5 \mu \mathrm{M})$. Immediately after treatment they were fixed with $4 \%$ paraformaldehyde in PB buffer $(0.12 \mathrm{M}$ phosphate, $\mathrm{pH} 7.4)$ for $30 \mathrm{~min}$ at room temperature. Microfilaments were stained by incubations with rhodamine-conjugated phalloidin $(0.66 \mu \mathrm{M}$; Molecular Probes, Eugene, OR) in PBS with $1 \%$ Triton $\mathrm{X}-100$ for $30 \mathrm{~min}$ at room temperature. For analysis of microtubules, the cells were permeabilized after fixation with $1 \%$ Triton X-100 in PBS for $20 \mathrm{~min}$ at room temperature, then incubated with a polyclonal antitubulin antibody (Biogenex; dilution 1:1 in PBS, $2 \%$ BSA, 2\% FCS, $2 \%$ Triton X-100) for $3-4 \mathrm{hr}$ at room temperature or over night at $4^{\circ} \mathrm{C}$. The secondary antibody (a FITC-coupled anti-rabbit IgG; Cappel, 55662) was applied at a dilution of $1: 200$ in PBS with $1 \%$ Triton X-100 for 1$2 \mathrm{hr}$ at room temperature. The cells were mounted in PBS containing $50 \%$ glycerol, $0.5 \% n$-propyl-gallate, and $2.5 \% \mathrm{NaI}$. In control experiments primary antibodies were omitted or the cells were incubated with a $100 \times$ excess of unlabeled phalloidin. No staining was observed in the neurites of these cells.

\section{Results}

\section{Effect of depolarization on growth cone behavior of leech neurons}

Leech neurons growing on a substrate of ECM show rounding up of the peripheral areas of the growth cone and neurite retraction after depolarization with high $\mathrm{K}^{+}$medium (Neely, 1993). The behavior of a typical set of growth cones under control 

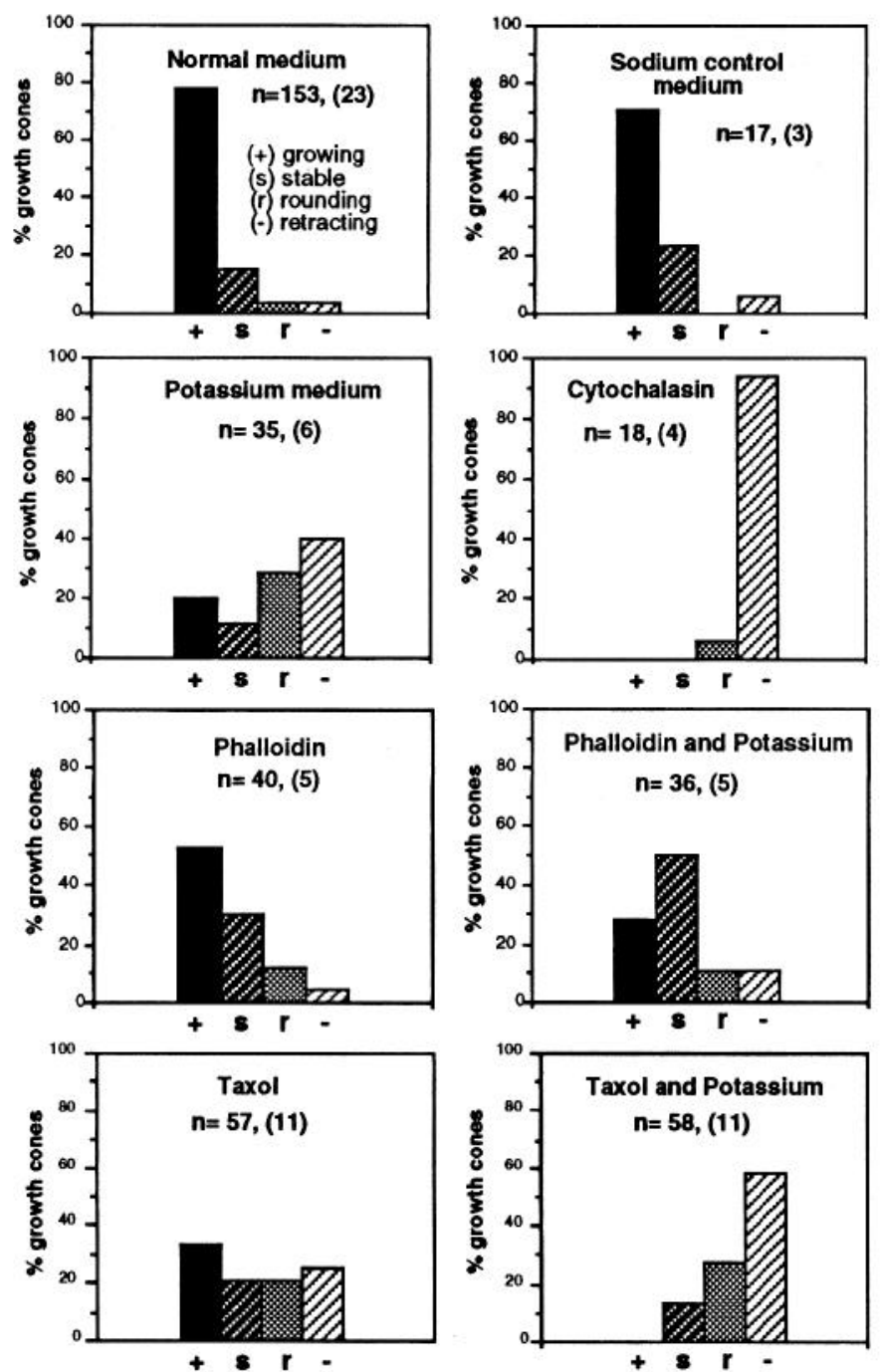

Figure 2. Growth cone morphology of neurites in normal medium, high $\mathrm{K}^{+}$medium, or media containing different cytoskeletal drugs was evaluated after $1 \mathrm{hr}$ and qualified as either growing $(+)$, stable $(s)$, rounding $(r)$, or retracting $(-) ; n$, number of growth cones analyzed; ( ), number of cells analyzed. Depolarization with high $\mathrm{K}^{+}$medium or treatment with $0.2 \mu \mathrm{M}$ cytochalasin D caused a significant increase of the percentage of growth cones with rounded morphology and growth cones that retracted, when compared to growth cones in normal medium or $\mathrm{Na}^{+}$control medium $(p<0.001)$. Treatment of neurons with $10 \mu \mathrm{M}$ phalloidin resulted in a significant inhibition of growth cone rounding and retraction after depolarization when compared to neurons treated with high $\mathrm{K}^{+}$medium only $(p<0.001)$. Taxol $(5 \mu \mathrm{M})$ did not inhibit these typical morphological changes after depolarization.

conditions is shown in Figure $1 A$. In normal medium over a period of $1 \mathrm{hr}, 93 \%$ of the neurites extended, sent out new filopodia, changed direction, or made new branches; the remaining $7 \%$ showed rounding of the growth cones or retraction (Fig. 2). The growth rate was approximately one to two growth cone diameters per hour $(10-20 \mu \mathrm{m} / \mathrm{hr})$.

Figure $1 B$ shows the response of a typical set of growth cones to depolarization. After 20-30 min of depolarization by raised external $\mathrm{K}^{+}$, growth cones started to round up and some neurites retracted. After $1 \mathrm{hr}, 69 \%$ of the growth cones showed rounding up of the peripheral areas or had retracted; only $31 \%$ showed signs of motility or neurite outgrowth (Fig. 2). Neurons exposed to $\mathrm{Na}^{+}$control medium showed neurite outgrowth that was
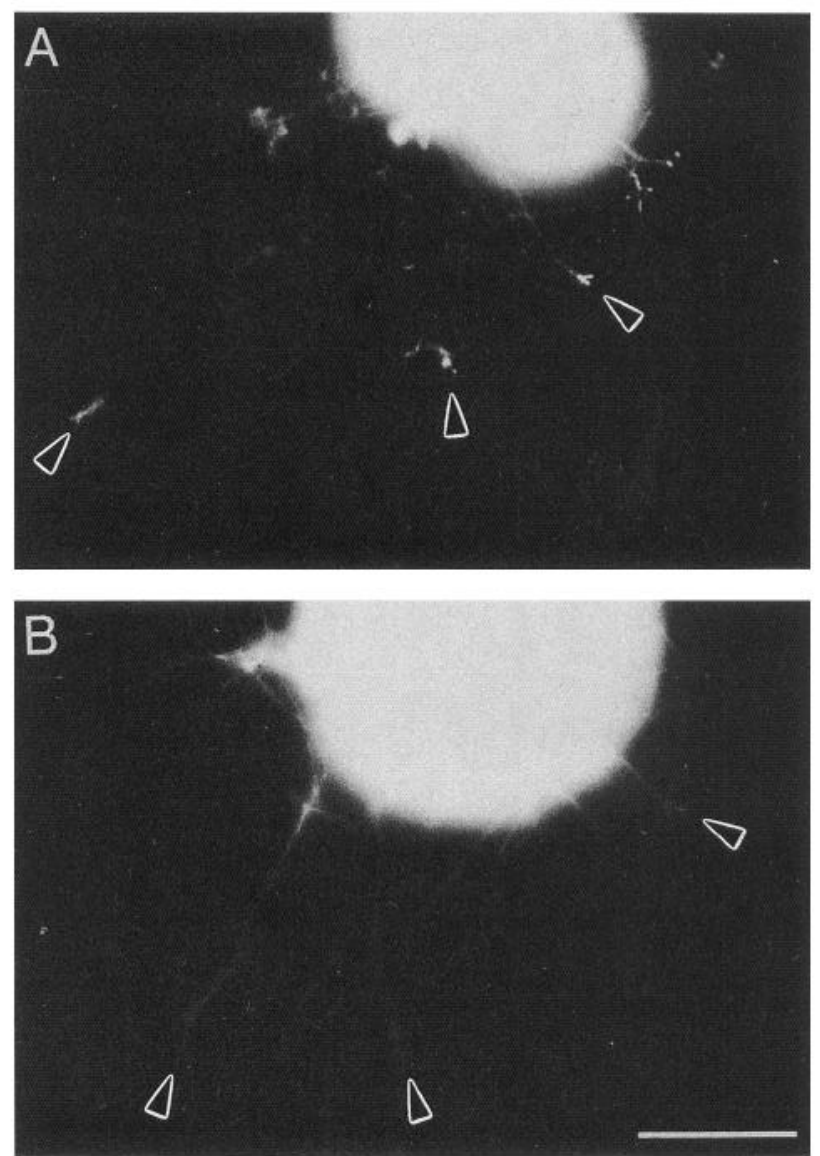

Figure 3. A, An AP neuron in normal medium growing on ECM was stained with rhodamine phalloidin. Microfilaments are visible at the tips of the neurites (arrowheads). B. This Retzius cell was depolarized for $20 \mathrm{~min}$ before it was stained with rhodamine phalloidin. The microfilament staining at the tips of the neurites is much reduced (arrowheads). Scale bar, $50 \mu \mathrm{m}$.

indistinguishable from the growth of neurites in normal medium (Fig. 2).

\section{Effect of depolarization and calcium entry on the cytoskeletal organization in growth cones}

The effect of depolarization on the cytoskeleton of leech neurons on ECM was analyzed by immunocytochemistry. Staining with rhodamine-phalloidin revealed abundant microfilaments in the distal ends of neurites and in growth cones of control neurons (Fig. 3A, arrowheads). Depolarization on ECM for 20-30 min was accompanied by a severe loss of microfilaments in these areas of the neurites (Fig. $3 B$, arrowheads).

Leech neurons growing on a different substrate, the plant lectin ConA, do not retract their neurites, but continue to grow after depolarization (Grumbacher-Reinert and Nicholls, 1992; Neely, 1993). The microfilament distributions in control and depolarized neurons on ConA were indistinguishable. Leech neurons in normal medium (Fig. 4A) and high $\mathrm{K}^{+}$medium (Fig. $4 C$ ) both showed intense staining in the distal parts of their processes. The overall microtubule distribution was also the same for control (Fig. 4B) and depolarized (Fig. 4D) cells on ConA. Microtubules lie mostly parallel to the long axis of the cell processes. Occasionally we observed some curling of the microtubules toward the distal parts of the neurites. 

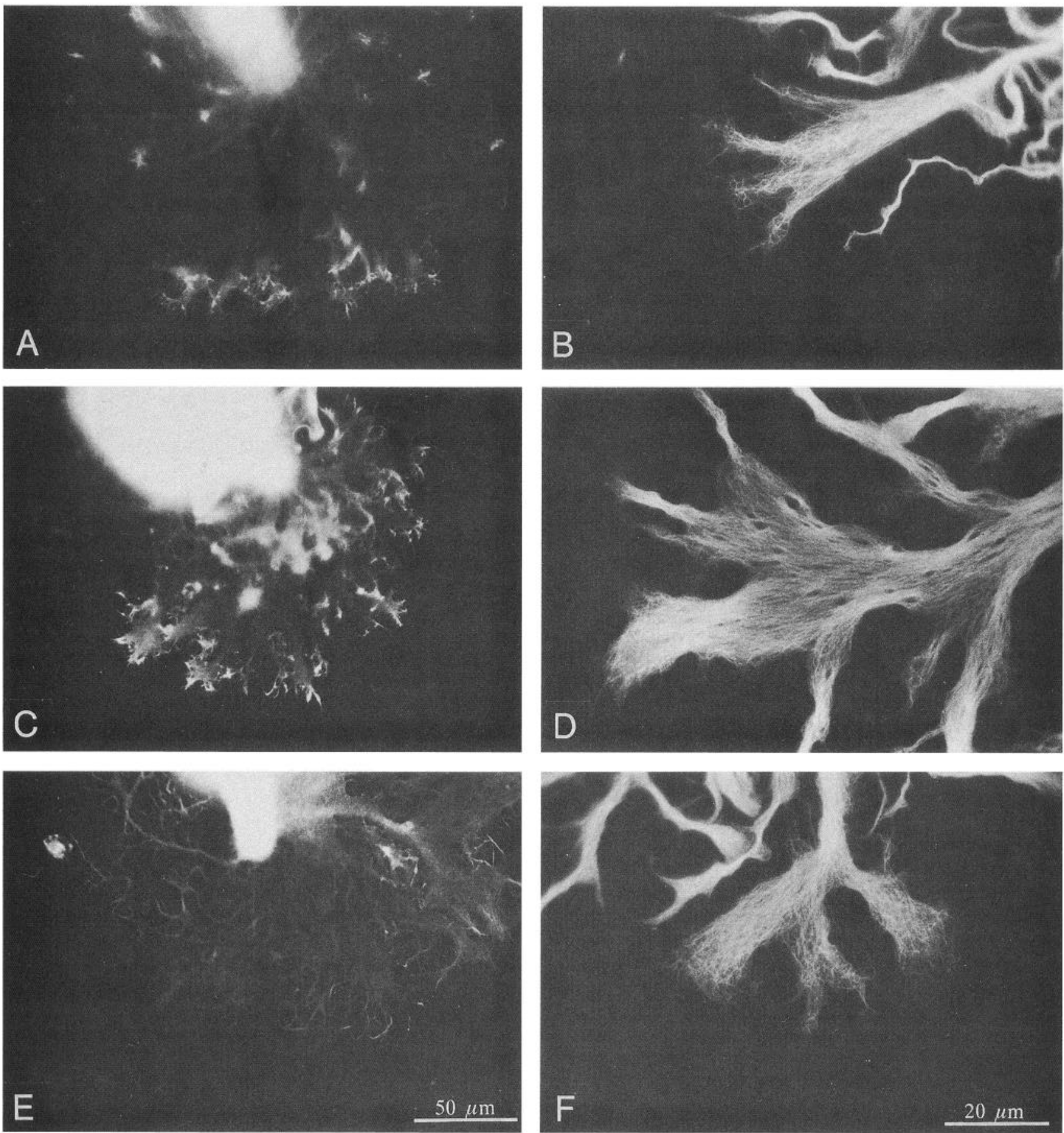

Figure 4. The cytoskeletal organization of leech neurons on ConA was analyzed with immunofluorescence. $A, C$, and $E$ show neurons that were stained with rhodamine phalloidin to visualize microfilaments. $B, D$, and $F$ display neurons that were stained with an antibody against tubulin. $A$ (Retzius) and $B$ (AP) show control cells; $C$ (Retzius) and $D$ (AP) were depolarized for $20 \mathrm{~min}$; the AP neurons shown in $E$ and $F$ were treated with the calcium ionophore A23187 ( $0.25 \mu \mathrm{M}$ and $0.1 \mu \mathrm{M}$, respectively). Depolarization had no effect on the microfilament distribution in neurites on ConA, whereas treatment with calcium ionophore led to loss of microfilaments. The distribution of the microtubules after depolarization or incubation with calcium ionophore was the same as in control cells. Scale bars: $A, C$, and $E, 50 \mu \mathrm{m} ; B, D$, and $F, 20 \mu \mathrm{m}$.

Influx of calcium is necessary for depolarization to induce neurite retraction of leech neurons on ECM (Neely, 1993). Leech neurons on ConA exhibit fewer voltage-dependent calcium channels in their processes than those on ECM (Ross et al., 1988). Hence, reduced calcium influx into neurons on ConA after depolarization might explain the lack of retraction in these cells (Grumbacher-Reinert and Nicholls, 1992; Neely, 1993).
We therefore analyzed the effect of raising the intracellular calcium concentration in neurons growing on ConA. Figure 5 shows time-lapse pictures of an AP neuron that was observed during $1 \mathrm{hr} 40 \mathrm{~min}$ in control conditions $(A)$ and then during a $1 \mathrm{hr}$ incubation with $0.1 \mu \mathrm{M}$ calcium ionophore A23187 $(B)$. This treatment led to cessation of growth cone motility and retraction of some lamellipodia (Fig. $5 B$, arrowheads). Saltatory, bidirec- 

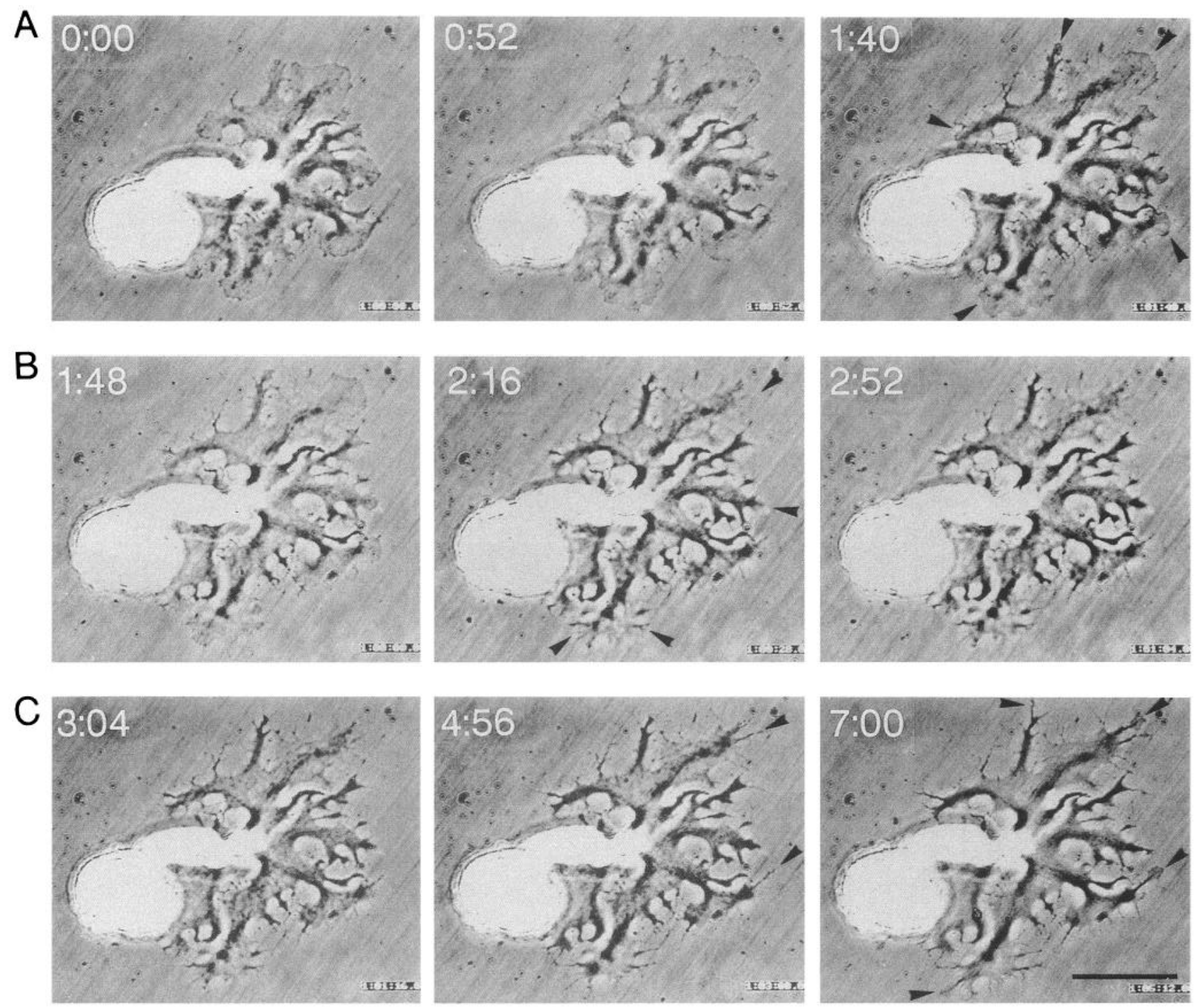

Figure 5. This AP neuron showed extensive neurite extension during $1 \mathrm{hr} 40 \mathrm{~min}$ in normal medium $(A$, arrowheads). Incubation with the calcium ionophore A23187 $(0.1 \mu \mathrm{M})$ led to cessation of growth cone motility and retraction of some of the lamellipodia $(B$, arrowheads). After $2 \mathrm{hr}$ of recovery in normal medium, elongation of some neurites was visible, and after $4 \mathrm{hr}$, the cell showed extensive neurite outgrowth (C, arrowheads). Scale bar, $50 \mu \mathrm{m}$.

tional intracellular particle movements, however, were still visible (not shown). After $1 \mathrm{hr}$ the A23187-medium was replaced with normal medium (Fig. 5C). Filopodial activity resumed within $2 \mathrm{hr}$ of recovery and neurites began to extend (Fig. $5 C$, arrowheads). Quantitative analysis revealed a significant decrease of the percentage of growing neurites from $44 \%$ observed in control cells to $17 \%$ in neurons exposed to calcium ionophore $(0.2 \mu \mathrm{M})\left[p<0.001 ; n_{\mathrm{A} 23187}=232(10) ; n_{\mathrm{ctrl}}=243(11) ; n\right.$, number of growth cones analyzed; ( ), number of cells analyzed]. High concentrations ( $1 \mu \mathrm{M}$ and higher) of ionophore killed the neurons.

These ionophore-induced changes in growth cone motility were accompanied by alterations in the organization of the microfilaments. Figure $4 E$ shows the distribution of microfilaments in an AP neuron after treatment with calcium ionophore for $30 \mathrm{~min}$. A drastic loss of microfilaments was observed in the neurites of ionophore-treated cells when compared with control cells (Fig. 4A). This loss was concentration dependent

\begin{tabular}{|c|c|c|}
\hline $\begin{array}{l}\text { Ionophore } \\
\text { concentration } \\
(\mu \mathrm{M})\end{array}$ & $\begin{array}{l}\text { Number of cells with } \\
\text { MF in neurites/cells } \\
\text { analyzed }\end{array}$ & $\begin{array}{l}\% \text { Cells with } \\
\text { MF in neurites }\end{array}$ \\
\hline 0.000 & $14 / 15$ & $93 \%$ \\
\hline 0.060 & $7 / 8$ & $87 \%$ \\
\hline 0.125 & $6 / 14$ & $43 \%$ \\
\hline 0.250 & $1 / 17$ & $6 \%$ \\
\hline 0.500 & $0 / 9$ & $0 \%$ \\
\hline
\end{tabular}

Leech neurons (Retzius and AP) were incubated with the calcium ionophore A23187 for $30 \mathrm{~min}$ and then stained with rhodamine phalloidin. The number of cells that contained any recognizable microfilaments in neurites was counted. Loss of microfilaments was dependent on the ionophore concentration used. MF, microfilaments. 

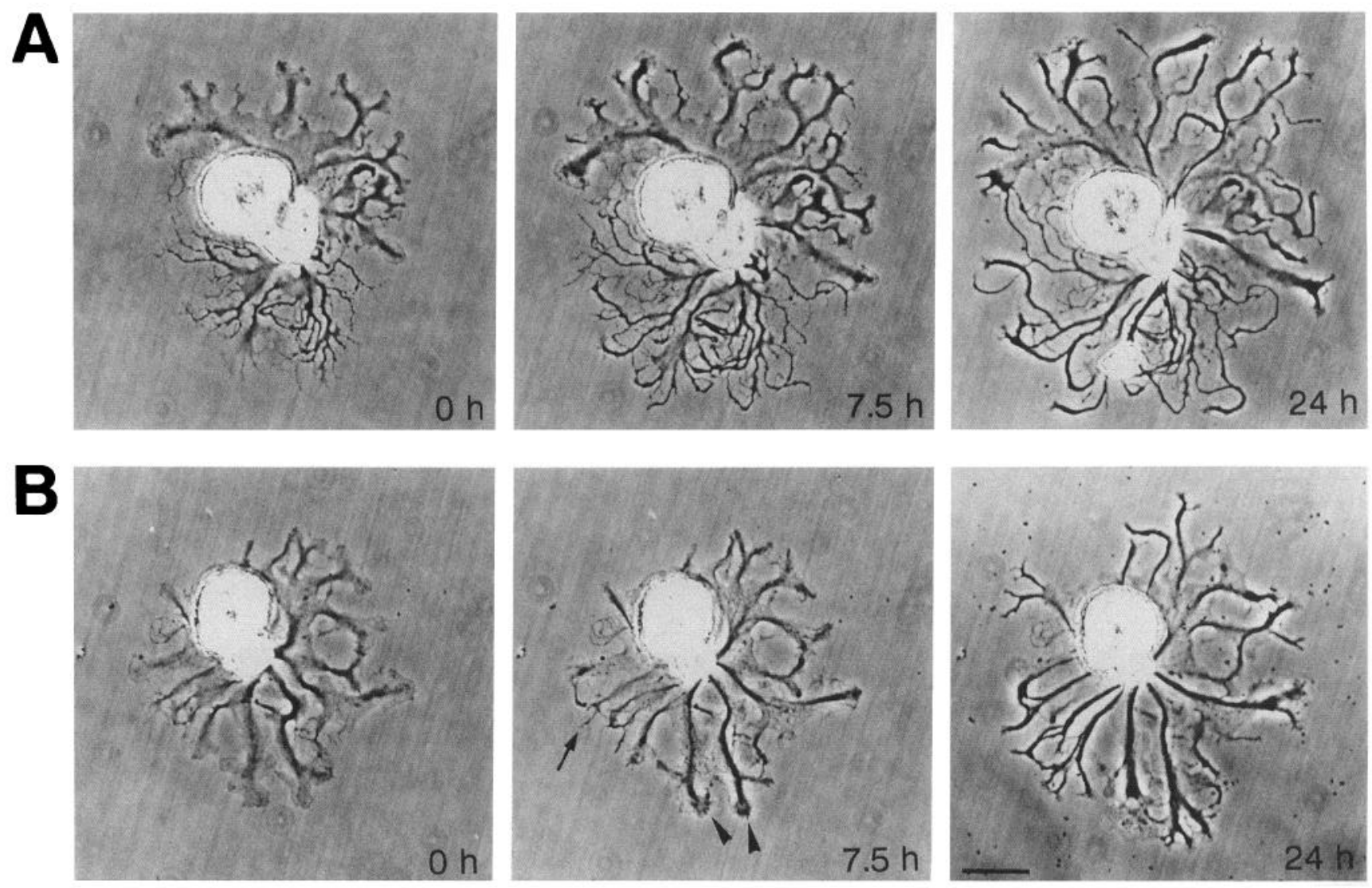

Figure 6. Cytochalasin D elicits similar changes in growth cone behavior as treatment with calcium ionophore. AP neurons were incubated with normal medium $(A)$ or normal medium with $10 \mu \mathrm{M}$ cytochalasin $\mathrm{D}(B)$ for $7.5 \mathrm{hr}$. During this time the control cell grew extensively $(A)$, whereas the neuron treated with cytochalasin did not elongate its neurites $(B)$. Some of its veils retracted $(B$, arrowheads) and some of its finer processes thickened $(B, a r r o w)$. Both neurons showed extensive outgrowth at $24 \mathrm{hr}$, after a $16.5 \mathrm{hr}$ recovery phase in normal medium. Scale bar, $50 \mu \mathrm{m}$.

(Table 1). Sometimes after treatment with lower ionophore concentrations the staining pattern had a spotty appearance (not shown). Microtubule distribution was not affected by treatment with calcium ionophore (Fig. $4 F$ ).

\section{Disruption of microfilaments with cytochalasin D}

These observations suggest that depolarization and the resulting calcium influx cause disruption of microfilaments which, in turn, leads growth cones to collapse. Disrupting microfilaments with cytochalasin D (Cooper, 1987) should, therefore, also result in growth cone collapse and neurite retraction. Application of cytochalasin D to neurons growing on ConA resulted in morphological changes similar to those seen after treatment with the calcium ionophore. Figure $6 B$ shows an AP neuron before and after $7.5 \mathrm{hr}$ treatment with cytochalasin D. Neurite outgrowth was inhibited, lamellipodia often retracted (arrowheads), and we frequently observed a thickening of thin neurites (arrow). After removal of cytochalasin, neurites resumed motility and started regrowing (Fig. 6B). Time-lapse studies revealed that filopodial activity stopped within min of cytochalasin application and resumed within min of its removal. Interestingly, organelle transport within neurites and filopodia persisted during cytochalasin exposure (not shown).

These results are summarized in Figure 7. While control neurites elongated to $177.9 \pm 6.7 \%$ (SE) of the starting total neurite length within $3.7 \mathrm{hr}$, cells exposed to cytochalasin D at $10 \mu \mathrm{M}$, $5 \mu \mathrm{M}$, or $2.5 \mu \mathrm{M}$ extended their neurites to an average of 105.2 $\pm 10.2 \%( \pm \mathrm{SE}), 111.7 \pm 8.7 \%$, and $122.3 \pm 9.2 \%$, respectively. (Immunofluorescent studies showed that $2.5 \mu \mathrm{M}$ cytochalasin D was sufficient to disrupt most of the microfilaments in growth cones; not shown.) During a $15 \mathrm{hr}$ recovery period, cytochalasin D-treated neurons regained their ability to extend neurites and their elongation rates were comparable to control cells (Fig. 7, inset). Three additional experiments yielded similar results.

Growth cones of Retzius cells growing on a substrate of ECM were analyzed with time-lapse video microscopy during a 60 min control period (Fig. $8 A$ ), followed by a $60 \mathrm{~min}$ incubation with $2 \mu \mathrm{M}$ cytochalasin D (Fig. $8 B$ ). Within 4 to 8 min many growth cones collapsed and neurites retracted, often leaving behind thin retraction fibers (Fig. 8B, arrowheads). Within 60 $\min 100 \%$ of the cytochalasin-treated growth cones had collapsed or retracted; only $7 \%$ of control neurites showed this behavior (Fig. 2). Thus, neurons growing on ECM treated with cytochalasin behave like neurons exposed to high $\mathrm{K}^{+}$medium, except that retraction was faster and more extensive in the presence of cytochalasin (Fig. 2).

\section{Stabilization of microfilaments with phalloidin}

Figure $9 A$ shows the behavior of neurites during a $1 \mathrm{hr}$ incubation with $10 \mu \mathrm{M}$ phalloidin, a microfilament-stabilizing agent (Cooper, 1987). Phalloidin had no effect on growth cone morphology and the neurites continued to grow (arrowheads). We observed, however, a smaller number of neurites that extended 


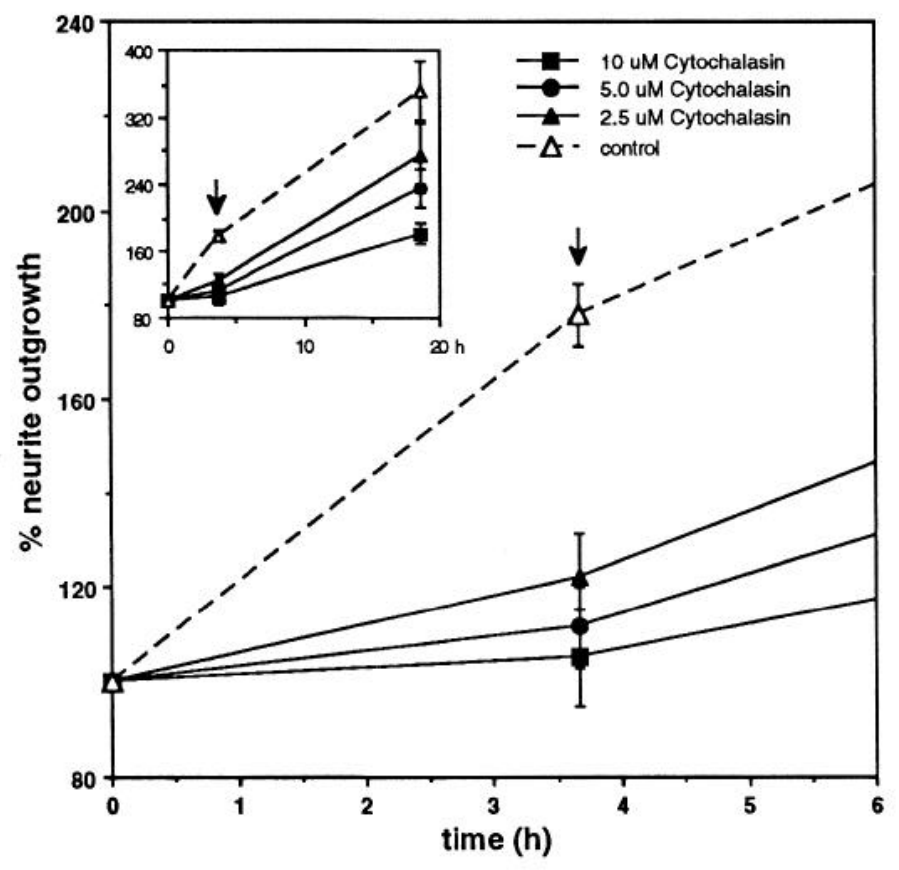

Figure 7. Cytochalasin inhibited neurite outgrowth of Retzius and AP cells on ConA. The growth of neurons incubated in various concentrations of cytochalasin D $(10 \mu \mathrm{M}, 5 \mu \mathrm{M}$, or $2.5 \mu \mathrm{M})$ was analyzed after 3.7 hr. Inhibition of neurite outgrowth was significant at all cytochalasin concentrations tested when compared to control cells $\left(P_{\text {all concentrations }}<\right.$ $0.001 ; n_{10 \mathrm{MM}}=7 ; n_{5 \mathrm{MM}}=9 ; n_{2.5 \mathrm{MM}}=5 ; n_{\mathrm{ctrl}}=22 ; n$, number of cells). After cytochalasin treatment normal medium was added to the cells (arrow) and their growth analyzed after a $18.5 \mathrm{hr}$ recovery phase (inset). The growth of neurons previously treated with $5 \mu \mathrm{M}$ or $2.5 \mu \mathrm{M}$ cytochalasin D was statistically not different from the growth of controls; neurons incubated with $10 \mu \mathrm{M}$ grew slightly slower than control cells ( $p$ $<0.05)$.

(+, Fig. 2) (53\% for phalloidin-treated vs $78 \%$ for control neurites) and an increased number of growth cones that showed stable morphology (s, Fig. 2) (30\% in phalloidin-treated vs $15 \%$ in control growth cones). On the average, therefore, growth slowed in the presence of phalloidin. Following preincubation with phalloidin, these cells were exposed to high $\mathrm{K}^{+}$medium in the presence of phalloidin $(10 \mu \mathrm{M})$. This drug inhibited rounding up and retraction of growth cones after depolarization (Fig. 9B). Only $22 \%$ of the growth cones rounded up or retracted, compared to $69 \%$ of the neurites that showed these morphological changes when treated with high $\mathrm{K}^{+}$without phalloidin (Fig. 2). We observed a further slowing of growth after incubation with phalloidin and high $\mathrm{K}^{+}$, when compared to the growth of neurites incubated with phalloidin only. This was manifested by the higher population of growth cones with stable morphology in cells treated with phalloidin in high $\mathrm{K}^{+}$medium $(50 \%)$ than in neurons treated with phalloidin only $(30 \%)$ and the smaller population of extending growth cones ( $28 \%$ vs $53 \%$; Fig. 2). This slowing of neurite outgrowth might be due to an additional metabolic burden on the cell induced by depolarization and the concomitant calcium influx.

\section{Stabilization of microtubules with taxol}

To test whether stabilization of the other cytoskeletal element of the growth cone, the microtubules, has an effect on the response to depolarization, we exposed the neurons to $5 \mu \mathrm{M}$ taxol, a microtubule stabilizing drug (Horwitz et al., 1982). (Immunocytochemical studies showed that this concentration of taxol
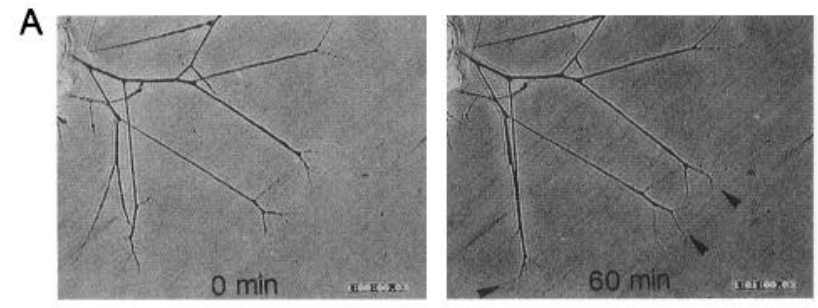

B
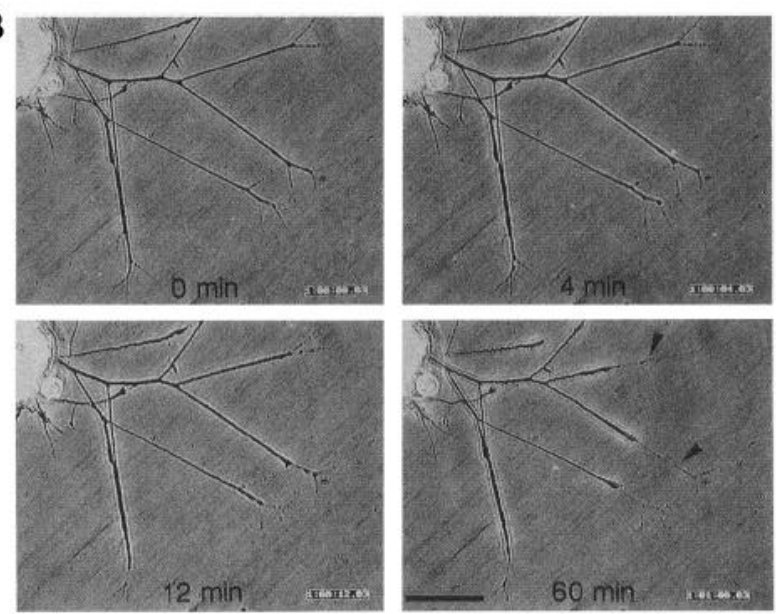

Figure 8. Effect of cytochalasin D on growth cones growing on ECM. A Retzius cell that was extending neurites on ECM during a 60 min control period ( $A$, arrowheads) was incubated with $2 \mu \mathrm{M}$ cytochalasin $(B)$. Within $12 \mathrm{~min}$ the growth cones had rounded up and some neurites had retracted. After $60 \mathrm{~min}$, all the neurites had retracted, leaving behind thin retraction fibers $(B$, arrowheads). Scale bar, $50 \mu \mathrm{m}$.

inhibits depolymerization of microtubules by nocodazole in leech neurons; not shown.) Neurons on ECM were incubated with taxol for $1 \mathrm{hr}$ (Fig. 10A), followed by incubation with high $\mathrm{K}^{+}$ medium containing $5 \mu \mathrm{M}$ of the same drug (Fig. 10B). Taxol itself reduced the number of actively growing and stable neurites ( $54 \%$ vs $93 \%$ for control neurites) and increased the population of growth cones that rounded up or retracted $(46 \%$ vs $7 \%$ for control growth cones; Fig. 2). Depolarization of neurons in the presence of taxol resulted in additional rounding of growth cones and neurite retraction, a response similar to the one observed after treating neurons with high $\mathrm{K}^{+}$medium only; $25 \%$ of the growth cones showed rounded morphology (vs $29 \%$ of neurites treated with high $\mathrm{K}^{+}$only) and $60 \%$ of the neurites retracted (vs $40 \%$ of neurites treated with high $\mathrm{K}^{+}$only; Fig. 2). Although taxol by itself has some inhibitory effect on neurite outgrowth, we conclude that stabilization of the microtubules does not prevent depolarization-induced neurite retraction. These results correlate well with our immunohistochemical analysis that revealed no changes in microtubule distribution after elevation of intracellular calcium (Fig. $4 F$ ).

\section{Discussion}

Our results show that morphological changes induced by depolarization of leech neurons on ECM, were accompanied by a loss of microfilaments in the growth cones. These responses were largely prevented by stabilization of microfilaments with phalloidin. The influx of calcium is a necessary event in the depolarization-induced retraction of neurites growing on ECM (Grumbacher-Reinert and Nicholls, 1992; Neely, 1993). That 

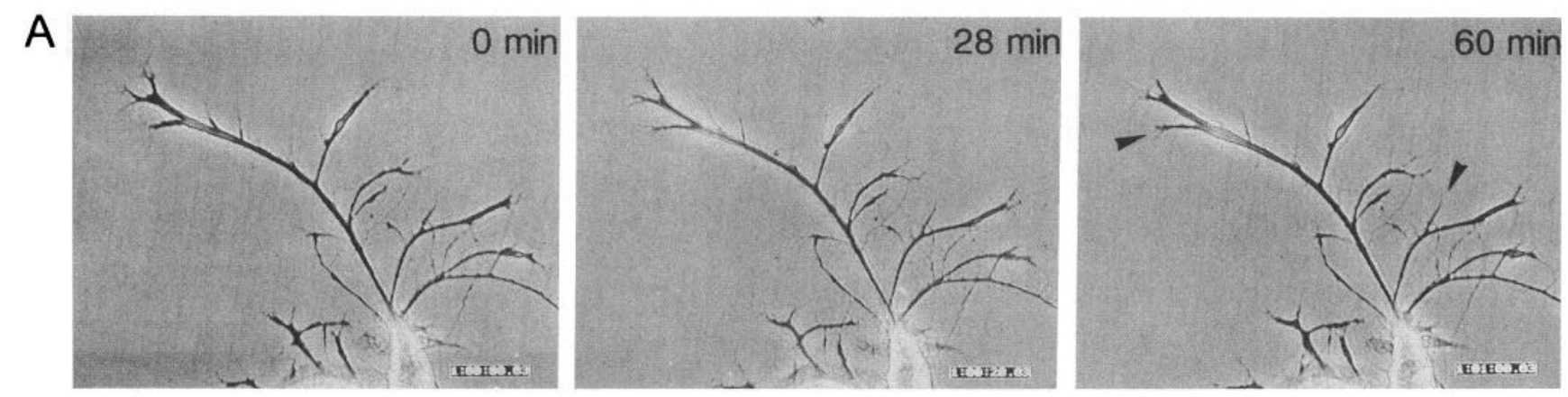

B
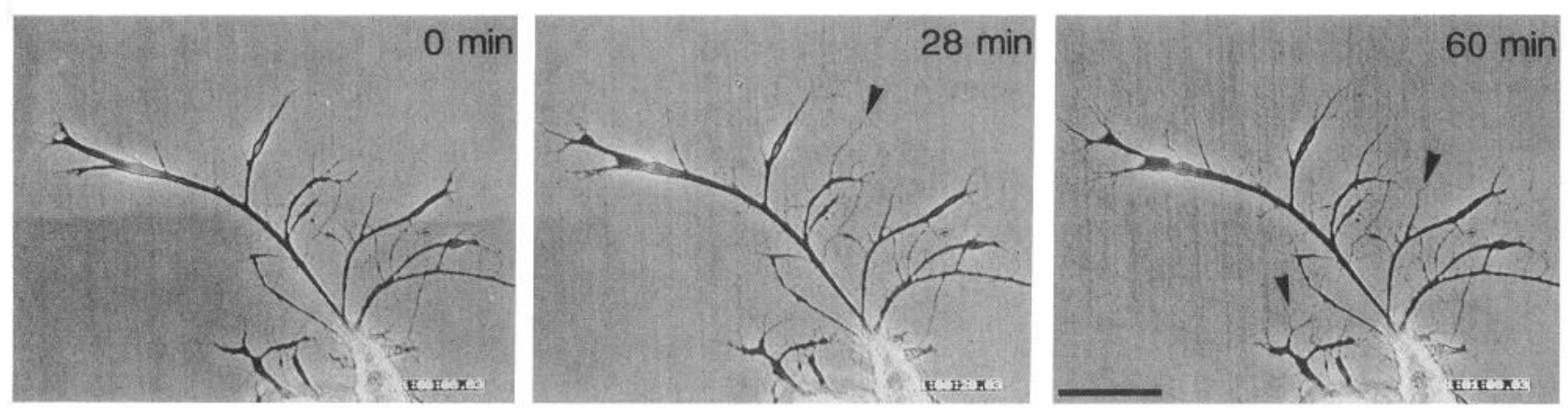

Figure 9. The effect of microfilament stabilization with phalloidin on growth cone morphology after depolarization. A Retzius neuron growing on ECM was first incubated for several hr with $10 \mu \mathrm{M}$ phalloidin $(A)$. The behavior of the growth cones during $1 \mathrm{hr}$ was recorded. During this time, some of the neurites extended ( $A$, arrowheads), while the other growth cones remained stationary, displaying typical stable growth cone morphology and filopodia. Then the neuron was exposed to high $\mathrm{K}^{+}$medium in the presence of $10 \mu \mathrm{M}$ phalloidin $(B)$. This treatment did not result in rounding or retraction of growth cones, and some neurites continued to extend ( $B$, arrowheads). Scale bar, $50 \mu \mathrm{m}$.

the reduced number of voltage-dependent calcium channels in neurites growing on another substrate, ConA (Ross et al., 1988), might be responsible for the lack of responsiveness of these cells to depolarization (Grumbacher and Nicholls, 1992; Neely, 1993) was supported by our finding that raising the intracellular calcium concentration led to loss of microfilaments and to cessation of growth cone motility.

In several types of neurons, disruption of microfilaments with

\section{A}
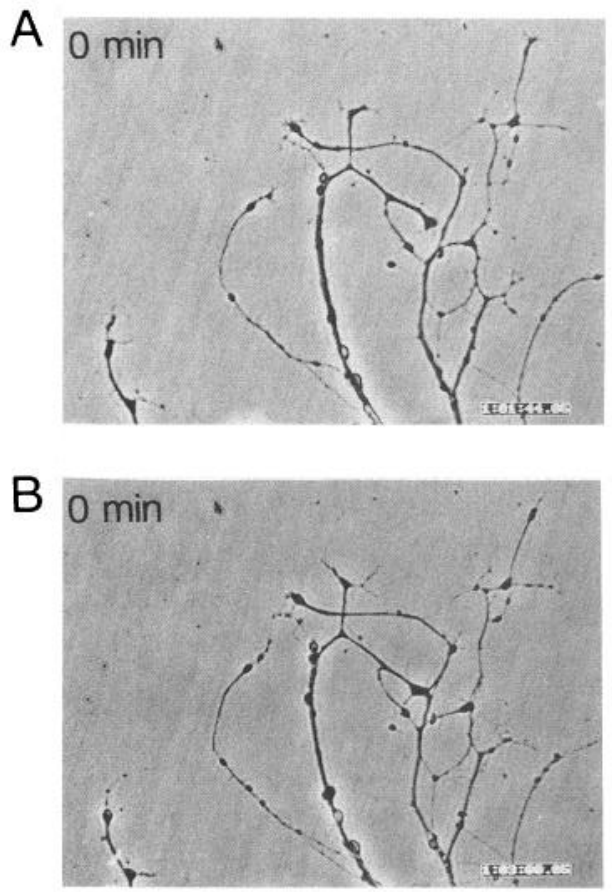
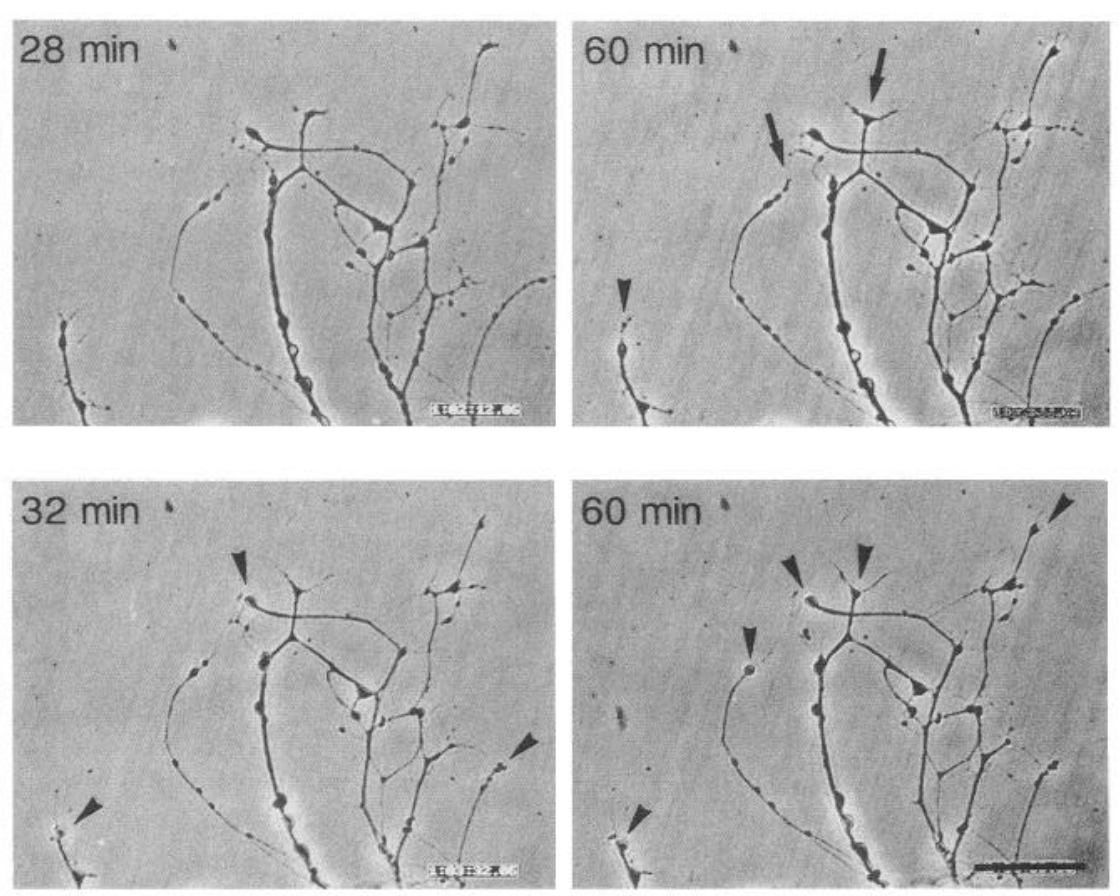

Figure 10. Treatment of leech neurons with the microtubule stabilizing drug taxol did not change the response of growth cones to depolarization. An AP neuron that was incubated for $60 \mathrm{~min}$ with taxol alone is shown $(A)$. During this time, some of the neurites continued to extend $(A$, arrows), but a few showed signs of rounding or even retraction $(A$, arrowhead $)$. Incubation with high $\mathrm{K}^{+}$medium in the presence of taxol resulted in a rounded morphology and retraction of most neurites $(B$, arrowheads). Scale bar, $50 \mu \mathrm{m}$. 
cytochalasin has been shown to change growth cone morphology and inhibit neurite outgrowth (Yamada et al., 1970, 1971; Marsh and Letourneau, 1984; Bentley and Toroian-Raymond, 1986; Chien et al., 1993; Fan et al., 1993). Loss of microfilaments after elevation of intracellular calcium evidently causes cessation of growth cone motility and neurite elongation in leech neurons, for we found that treatment of leech neurons with cytochalasin D induces similar morphological changes and, significantly, that stabilization of the microfilaments with phalloidin prevents them. We cannot, however, exclude the additional involvement of other components of the cytoskeleton, or changes in axonal transport or cellular metabolism.

In principle, growth cone collapse and retraction of neurites could be a result of contraction, rather than loss of microfilaments. If contraction were responsible for the morphological changes, however, microfilaments should be redistributed toward the center of the growth cone. What we observed was a loss of microfilaments from the peripheral areas of the growth cone, without increase of staining in the central parts of the growth cones. Our data therefore support a mechanism by which calcium causes microfilament disruption rather than contraction.

The molecular mechanism by which calcium might influence the structure and motility of the growth cone are still largely unknown. Disruption of microfilaments by elevated intracellular calcium has also been shown in vertebrate neurons. In that study, additional destabilization of microtubules was observed (Lankford and Letourneau, 1989). In our experiments, depolarization or elevation of intracellular calcium had no effect on the distribution of microtubules, and stabilization of microtubules did not reduce or inhibit growth cone collapse or neurite retraction. Calcium has also been shown to affect the organization of the cytoskeleton in some non-neuronal cells (Stolz and Bereiter-Hahn, 1988a,b). We observed that the microfilaments of microglial cells that coisolate with leech neurons are also disrupted after calcium ionophore treatment; however, 10 times higher concentrations of calcium ionophore were necessary (Neely, unpublished observation). This cell type-specific response of microfilaments to the elevation of intracellular calcium concentration might be due to different calcium target molecules or to differences in the calcium sensitivities of isoforms of such target molecules in different cell types.

The cytoskeleton is organized by microtubule- and microfilament-associated proteins. Some of these proteins bind to their filaments in a calcium-dependent manner and calcium ions could therefore influence the cytoskeletal organization by regulating the activity of these proteins (Stossel et al., 1985; Olmsted, 1986; Vandekerckhove, 1990). Gelsolin acts as a microfilament-capping and -severing protein, but only upon binding of calcium (Stossel et al., 1985). One could therefore imagine that the local influx of calcium causes an activation of gelsolin, which then severs the microfilaments. Microinjection of a constitutively activated form of gelsolin into fibroblasts or macrophages causes these cells to round up, inhibits membrane ruffling, and induces loss of stress fibers (Cooper et al., 1987). We have recently observed an antigen that colocalizes with microfilaments in growth cones of leech neurons and cross-reacts with antibodies against gelsolin (Neely, unpublished observation).

Depolarization and the concomitant calcium influx could also affect the cytoskeleton through modification of cytoskeletonassociated proteins by calcium-dependent second-messenger cascades (Schliwa et al., 1981; Yamauchi and Fujisawa, 1983,
1988; Vallano et al., 1985). KCl-induced membrane depolarization leads to an increase in calcium/calmodulin-dependent kinase activity in extracts prepared from hippocampal slices (Hanson and Schulman, 1992), and calcium/calmodulin kinase II has recently been shown to affect neurite outgrowth (Goshima et al., 1993). Protein kinase $C$ is activated by depolarizationdependent calcium-influx into synaptosomes (Wu et al., 1982) and also influences the growth of neurites (Bixby, 1989; Lankford and Letourneau, 1991).

During development, a neuron is exposed to many different signals acting through different signal transduction pathways that may result in similar morphological changes. Electrical activity and the associated influx of calcium has been shown to cause rounding up of growth cones and cessation of neurite outgrowth in several types of neurons (Cohan et al., 1987; Kater et al., 1988; Cohan, 1992; Grumbacher-Reinert and Nicholls, 1992; Neely, 1993). Exposure of neurons to thrombin, a serine protease, leads to growth cone collapse and rapid retraction of processes (Gurwitz and Cunningham, 1988; Grand et al., 1989). This signal seems to be mediated by a calcium-independent protein kinase (Suidan et al., 1992). Recently, it has been shown that a membrane-associated factor from chick embryonic or adult CNS causes growth cone collapse of chick dorsal root neurons (Raper and Kapfhammer, 1990; Luo et al., 1993). The induced growth cone collapse seems not associated with an increase in intracellular calcium (Ivins et al., 1991). The collapse of these growth cones was accompanied by a loss of microfilaments, but no effect on microtubules was observed (Fan et al., 1993). The observations made by Fan et al. (1993) and our results suggest that different signal transduction pathways can ultimately converge and result in the same cytoskeletal and morphological changes. It is attractive to speculate about the pathways by which these different signaling mechanisms act and to determine where they converge to regulate neuronal differentiation.

\section{References}

Anglister L, Farber IC, Shahar A, Grinvald A (1982) Localization of voltage-sensitive calcium channels along developing neurites: their possible role in regulating neurite elongation. Dev Biol 94:351-365.

Bentley D, Toroian-Raymond A (1986) Disoriented pathfinding by pioneer neurone growth cones deprived of filopodia by cytochalasin treatment. Nature 323:712-715.

Bixby JL (1989) Protein kinase C is involved in laminin stimulation of neurite outgrowth. Neuron 3:287-297.

Budnik V, Zhong Y, Wu C-F (1990) Morphological plasticity of motor axons in Drosophila mutants with altered excitability. J Neurosci 10: 3754-3768.

Chien C-B, Rosenthal DE, Harris WA, Holt CE (1993) Navigational errors made by growth cones without filopodia in the embryonic Xenopus brain. Neuron 11:237-251.

Chiquet M, Masuda-Nakagawa L, Beck K (1988) Attachment to an endogenous laminin-like protein initiates sprouting by leech neurons. J Cell Biol 107:1189-1198.

Cohan CS (1992) Depolarization-induced changes in neurite elongation and intracellular $\mathrm{Ca}^{+}$in isolated Helisoma neurons. J Neurobiol 23:983-996.

Cohan CS, Kater SB (1986) Suppression of neurite elongation and growth cone motility by electrical activity. Science 232:1638-1640.

Cohan CS, Connor JA, Kater SB (1987) Electrically and chemically mediated increases in intracellular calcium in neuronal growth cones. J Neurosci 7:3588-3599.

Cooper JA (1987) Effects of cytochalasin and phalloidin on actin. J Cell Biol 105:1473-1478.

Cooper JA, Bryan J, Schwab B III, Frieden C, Loftus DJ (1987) Microinjection of gelsolin into living cells. J Cell Biol 104:491-501.

Dailey ME, Bridgman PC (1989) Dynamics of the endoplasmic retic- 
ulum and other membranous organelles in growth cones of cultured neurons. J Neurosci 9:1897-1909.

Dietzel ID, Drapeau P, Nicholls JG (1986) Voltage dependence of 5 -hydroxytryptamine release at a synapse between identified leech neurones in culture. J Physiol (Lond) 372:191-205.

Fan J, Mansfield SG, Redmond T, Gordon-Weeks PR, Raper JA (1993) The organization of F-actin and microtubules in growth cones exposed to a brain-derived collapsing factor. J Cell Biol 121:867-878.

Forscher P, Smith SJ (1988) Actions of cytochalasins on the organization of actin filaments and microtubules in a neuronal growth cone. J Cell Biol 107:1505-1516.

Fuchs PA, Nicholls JG, Ready DF (1981) Membrane properties and selective connexions of identified leech neurones in culture. J Physiol (Lond) 316:203-223.

Goshima Y, Ohsako S, Yamauchi T (1993) Overexpression of $\mathrm{Ca}^{2+} /$ calmodulin-dependent protein kinase II in neuro2a and NG108-15 neuroblastoma cell lines promotes neurite outgrowth and growth cone motility. J Neurosci 13:559-567.

Grand RJA, Grabham PW, Gallimore MJ, Gallimore PH (1989) Modulation of morphological differentiation of human neuroepithelial cells by serine proteases: independence from blood coagulation. EMBO J 8:2209-2215.

Grumbacher-Reinert S, Nicholls J (1992) Influence of substrate on retraction of neurites following electrical activity of leech Retzius cells in culture. J Exp Biol 167:1-14.

Gurwitz D, Cunningham DD (1988) Thrombin modulates and reverses neuroblastoma neurite outgrowth. Proc Natl Acad Sci USA 85:3440-3444.

Hanson PI, Schulman H (1992) Neuronal $\mathrm{Ca}^{2+} /$ calmodulin-dependent protein kinases. Annu Rev Biochem 61:559-601.

Heathcote RD, Sargent PB (1985) Loss of supernumerary axons during neuronal morphogenesis. J Neurosci 5:1940-1946.

Horwitz SB, Parness J, Schiff PB, Manfredi JJ (1982) Taxol: a new probe for studying the structure and function of microtubules. Cold Spring Harbor Symp Quant Biol 46:219-226.

Hubel DH, Wiesel TN (1970) The period of susceptibility to the physiological effects of unilateral eye closure in kittens. J Physiol (Lond) 206:419-436.

Innocenti GM (1981) Growth and reshaping of axons in the establishment of visual callosal connections. Science 212:824-827.

Ivins JK, Raper JA, Pittman RN (1991) Intracellular calcium levels do not change during contact-mediated collapse of chick DRG growth cone structure. J Neurosci 11:1597-1608.

Kater SB, Mattson MP, Cohan C, Connor J (1988) Calcium regulation of the neuronal growth cone. Trends Neurosci 11:315-321.

Lankford KL, Letourneau PC (1989) Evidence that calcium may control neurite outgrowth by regulating the stability of actin filaments. $J$ Cell Biol 109:1229-1243.

Lankford KL, Letourneau PC (1991) Roles of actin filaments and three second-messenger systems in short-term regulation of chick dorsal root ganglion neurite outgrowth. Cell Motil Cytoskel 20:7-29.

Letourneau PC, Ressler AH (1983) Differences in the organization of actin in the growth cones compared with the neurites of cultured neurons from chick embryos. J Cell Biol 97:963-973.

Letourneau PC, Ressler AH (1984) Inhibition of neurite initiation and growth by taxol. J Cell Biol 98:1355-1362.

Letourneau PC, Shattuck TA, Ressler AH (1986) Branching of sensory and sympathetic neurites in vitro is inhibited by treatment with taxol. J Neurosci 6:1912-1917.

Lnenicka GA, Murphey RK (1989) The refinement of invertebrate synapses during development. J Neurobiol 20:339-355.

Luduena MA, Wessells NK (1973) Cell locomotion, nerve elongation, and microfilaments. Dev Biol 30:427-440.

Luo Y, Raible D, Raper JA (1993) Collapsin: a protein in brain that induces the collapse and paralysis of neuronal growth cones. Cell 75: 217-227.

Mariani J, Changeux J-P (1981) Ontogenesis of olivocerebellar relationships. I. Studies by intracellular recordings of the multiple innervation of Purkinje cells by climbing fibers in the developing rat cerebellum. J Neurosci 1:696-702.
Marsh L, Letourneau PC (1984) Growth of neurites without filopodial or lamellipodial activity in the presence of cytochalasin B. J Cell Biol 99:2041-2047.

Neely MD (1993) Role of substrate and calcium in neurite retraction of leech neurons following depolarization. J Neurosci 13:1292-1301.

Olmsted JB (1986) Microtubule-associated proteins. Annu Rev Cell Biol 2:421-457.

Piatigorsky J, deF Webster H, Wollberg M (1972) Cell elongation in the cultured embryonic chick lens epithelium with and without protein synthesis. Involvement of microtubules. J Cell Biol 55:82-92.

Purves D, Lichtman. JW (1980) Elimination of synapses in the developing nervous system. Science 210:153-157.

Raper JA, Kapfhammer J (1990) The enrichment of a neuronal growth cone collapsing activity from embryonic chick brain. Neuron 2:2129.

Rehder V, Kater SB (1992) Regulation of neuronal growth cone filopodia by intracellular calcium. J Neurosci 12:3175-3186.

Ross WN, Arechiga H, Nicholls JG (1988) Influence of substrate on the distribution of calcium channels in identified leech neurons in culture. Proc Natl Acad Sci USA 85:4075-4078.

Schliwa M, Euteneuer U, Bulinski JC, Izant JG (1981) Calcium lability of cytoplasmic microtubules and its modulation by microtubule-associated proteins. Proc Natl Acad Sci USA 78:1037-1041.

Shatz CJ (1990) Impulse activity and the patterning of connections during CNS development. Neuron 5:745-756.

Spooner BS, Yamada KM, Wessells NK (1971) Microfilaments and cell locomotion. J Cell Biol 49:595-613.

Stolz B, Bereiter-Hahn J (1988a) Calcium sensitivity of microtubules changes during the cell cycle of Xenopus laevis tadpole endothelial cells. Cell Biol Int Rep 12:313-320.

Stolz B, Bereiter-Hahn J (1988b) Increase of cytosolic calcium results in formation of F-actin aggregates in endothelial cells. Cell Biol Int Rep 12:321-329.

Stossel TP, Chaponnier C, Ezzell RM, Hartwig JH, Janmey PA, Kwiatkowski DJ, Lind SE, Smith DB, Southwick FS, Yin HL, Zaner KS (1985) Nonmuscle actin-binding proteins. Annu Rev Cell Biol 1:353402.

Suidan HS, Stone SR, Hemmings BA, Monard D (1992) Thrombin causes neurite retraction in neuronal cells through activation of cell surface receptors. Neuron 8:363-375.

Vallano ML, Goldenring JR, Buckholk TM, Larson RE, DeLorenzo RJ (1985) Separation of endogenous calmodulin- and cAMP-dependent kinases from microtubule preparations. Proc Natl Acad Sci USA 82: 3202-3206.

Vandekerckhove J (1990) Actin-binding proteins. Curr Opin Cell Biol 2:41-50.

Wiesel TN, Hubel DH (1963) Effects of visual deprivation on morphology and physiology of cells in the cat's lateral geniculate body. $J$ Neurophysiol 26:978-993.

Wiesel TN, Hubel DH (1965) Comparison of the effects of unilateral and bilateral eye closure on cortical unit responses in kittens. J Neurophysiol 28:1029-1040.

Wu WC-S, Walaas SI, Nairn AC, Greengard P (1982) Calcium/phospholipid regulates phosphorylation of a $\mathrm{M}_{\mathrm{r}}$ " $87 \mathrm{k}$ " substrate protein in brain synaptosomes. Proc Natl Acad Sci USA 79:5249-5253.

Yamada KM, Spooner BS, Wessells NK (1970) Axon growth: roles of microfilaments and microtubules. Proc Natl Acad Sci USA 66: $1206-1212$

Yamada KM, Spooner BS, Wessells NK (1971) Ultrastructure and function of growth cones and axons of cultured nerve cells. J Cell Biol 49:614-635.

Yamauchi T, Fujisawa H (1983) Disassembly of microtubules by the action of calmodulin-dependent protein kinase (kinase II) which occurs only in the brain tissues. Biochem Biophys Res Commun 110: 287-291.

Yamauchi T, Fujisawa H (1988) Regulation of the interaction of actin filaments with microtubule-associated protein 2 by calmodulin-dependent protein kinase II. Biochim Biophys Acta 968:77-85. 